\title{
Proton-Coupled Amino Acid Transporter 1
}

National Cancer Institute

\section{Source}

National Cancer Institute. Proton-Coupled Amino Acid Transporter 1. NCI Thesaurus. Code C118921.

Proton-coupled amino acid transporter 1 ( $476 \mathrm{aa}, \sim 53 \mathrm{kDa}$ ) is encoded by the human SLC36A1 gene. This protein is involved in the transport of small amino acids and hydrogen ions. 